\title{
ALOCUÇĀO PROFERIDA PELO PROF. Dr. HÉLIO SILVA
}

As comemorações do cinqüentenário da Revolução de 1930 coloca em primeiro plano a figura de Getúlio Vargas. Porque nenhum outro de seus companheiros, mesmo entre os que, como Oswaldo Aranha e João Neves, primeiro forjaram a conspiração e armaram a Revolução, antes mesmo que o então Presidente do Rio Grande do Sul assumisse, publicamente, uma atitude, representa melhor aquele acontecimento.

A História trata dos homens discriminadamente. Há aqueles que ela menciona com maior ou menor destaque; os que esquece, inexoravelmente e desaparecem na poeira do tempo, até que um pesquisador minucioso vá revelar o que fizeram e não deixaram fortes vestigios.

Os novos que criticam o conceito clássico da História reclamam que o povo não aparece nesses acontecimentos que consagram os heróis. Uma tendência, que se vem acentuando, na moderna historiografia, denuncia uma solerte preocupação das elites em matar a memória, na tentativa de extinguir as reivindicações das massas, enquanto traçam a legenda dos séculos de uma maneira tendenciosa, de acordo com suas conveniências e interesses. Assim, nos regimes totalitários a História é refeita ao advento de cada novo ditador que manda apagar os nomens, os fatos e as datas em que não teve participação, ou desfavoráveis aos seus desígnios.

O movimento de outubro de 30 tem passado por numerosos eclipses. Ora ele é apresentadơ com as luzes de uma epopéia enquanto que, em outras fases da nossa História, seus homens e seus feitos merecem a crítica mais acerba.

Se, porém, a História discrimina os homens e os fatos que deve registrar, há homens que se sobrepõem a este critério. Porque não é a História que os consagra, uma vez que são eles que fazem a História. E por isso que Getúlio Vargas se destaca, e pode sintetizar o movimento de outubro de 1930.

A vida e a ação de Vargas se confundem e fundem na mais estranha personalidade que ocupou o cenário político do Brasil. Desde a sua infância, atrai os acontecimentos e molda as circunstâncias, como se um meteur-en-scène compusesse o cenário para a sua atuação.

Não obstante a riqueza de detalhes que valorizam cada episódio, das diferentes fases de sua vida, não é fácil traçar e acompanhar seu pensamento politico. Porque Vargas é um homem de ação, antes que um pensador. O moço 
que lia Darwin, Kant, Nietzsche, Spencer, Carlyle, Baudelaire e Zola não deve ter tido muito tempo para continuar as suas leituras, depois que ingressou na política. A extraordinária acuidade que caracterizava a sua inteligência cobria, através dos relatórios e das entrevistas, um material novo de que se servia em seus pronunciamentos. Mas aquelas leituras variadas, sem a disciplina de uma formação filosófica, longe de dificultar, pela inconsistência doutrinária, o desenvolvimento de sua personalidade politica, antes permitira-lhe uma disponibilidade de que se valeu em um periodo da história mundial caracterizada pela subversão dos valores, o abandono de filosofias, a crise do mundo moderno que eclodiu com a I Guerra Mundial e se prolonga até nossos dias na insegurança dos regimes e na instabilidade de seus líderes.

Nem se diga que Getúlio Vargas tínha por base filosófica o positivismo. Porque o que havia de positivismo em sua formação era o castilhismo, antes uma emanação da figura singular de Júlio de Castilhos, que não era um positivista ortodoxo. A doutrina castilhista teve a sua oportunidade na hora e no local em que viveu Júlio de Castilhos, isto é, na implantação da República, no domínio de Floriano, na luta sem tréguas contra Silveira Martins e seus liberais. Restou, é certo, uma estrutura político-partidária, o Partido Republicano, herdeiro da tradição de Júlio de Castilhos e obediente à direção firme de Borges de Medeiros. Mas se acompanharmos, atentamente, a trajetória política de Vargas logo constatamos que ele se distancia do cenário estadual e da sua influência política.

Quando Getúlio Vargas, volta ao Rio Grande, como Presidente eleito do Estado, sua visão política alargou-se a ponto de abranger todo o Rio Grande no movimento de unificação que lhe vai assegurar a retaguarda política para a campanha da Aliança Liberal. Um castilhista puro não teria essa visão que the permitiu chegar à Presidência da República e abriu, para o Rio Grande, novas perspectivas na politica federal, assegurando-lhe uma hegemonia que ainda não foi abalada.

E fácil definir a filosofia política de Vargas como oportunismo. Se colhermos os seus pronunciamentos, as suas atitudes, os seus atos, através de um longo periodo que começa na Assembléia Legislativa do Rio Grande e vai acabar, tragicamente, num quarto do Palácio do Catete encontramos contradições, incoerências, antagonismos, que bastariam para documentar esse conceito.

Mas se não sairmos do exame restrito dos documentos, para nos situarmos no ambiente em que foram produzidos será, antes, a afirmação do estadista que sente e até pressente as variações do momento político, nacional ou estrangeiro, e age certo no momento exato.

Deputado Estadual e líder da Assembléia é o fiel intérprete do pensamento do chefe do Partido Republicano, Borges de Medeiros. Assim também o lider da bancada federal do Rio Grande quando assegura ao Presidente da República, Arthur Bernardes a solidariedade do seu Estado por ocasião do levante do $1^{\circ} 5$ de julho. Era preciso. O Rio Grande combatera a candidatura Arthur Bernardes mas se reconciliara com ele com o Pacto de Pedras Altas, evitando a intervenção que os libertadores de Assis Brasil reclamavam. O que não impedirá que o candidato da Aliança Libertadora de chamar de Buenos Aires o chefe da Coluna Prestes para oferecer-lhe a chefia militar da Revolução.

Há, não um, mas uma sucessão de Getúlio Vargas: apresentação de deputado estadual; de parlamentar federal; de Presidente de Estado; de chefe da Revolução vitoriosa, empossado no Governo Provisório; de Presidente, eleito 
para Assembléia Nacional Constituinte, que lhe presta conta de seus atos; neopolítico hábil que capitaliza o golpe branco de 10 de novembro, urdido e reclamado pelos chefes militares; na figura do estadista que mantém a neutralidade do Brasil, enquanto conveniente aos seus interesses e não hesita em lançar o país na guerra, atendendo ao clamor do povo e marcando o seu lugar entre as grandes potências vitoriosas.

Em todas estas passagens e em muitas outras vamos encontrar, porém, as linhas mestras do nacionalismo e do populismo, na defesa intransigente da emancipação econômica do Brasil, que lhe custou a vida e o amor aos humildes, ao proletariado, ao povo que lhe asseguraria a imortalidade.

No rol dos mortos ilustres do Brasil não há outro tão vivo quanto Getúlio Vargas. A História Contemporânea não apresenta nenhum outro documento que tenha a vivência e atualidade da Carta Testamento por cuja herança ainda se batem os politicos.

Por isso o pensamento político de Vargas se desdobra adaptando-se às circunstâncias, refletindo as mudanças em uma plasticidade que em muito explica a longa duração do seu governo. É preciso, porém, reconhecer a firmeza de suas decisões a que devemos a Siderurgia, a Eletrobrás, a Petrobrás, a defesa da nossa riqueza mineral, a previsão da substituição do petróleo importado pelo álcool. Porque o estudo de sua obra e de seu governo revelam a mais completa visão dos problemas nacionais que já teve um homem de governo do Brasil. 